\title{
Practical Modeling of Aluminum Species in High-pH Waste
}

D. A. Reynolds

Date Published

October 1995

Prepared for the U.S. Department of Energy Assistant Secretary for Environmental Management

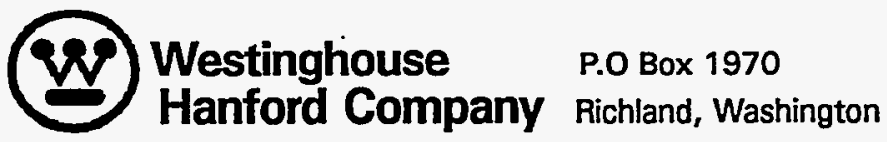

Management and Operations Contractor for the

U.S. Department of Energy under Contract DE-AC06-87RL10930

Approved for public release; distribution is unlimited 


\section{RELEASE AUTHORIZATION}

Document Number: WHC-EP-0872

Document Title: Practical Modeling of Aluminum Species in High-pH Waste

Release Date: $\quad 10 / 2 / 95$

This document was reviewed following the procedures described in WHC-CM-3-4 and is:

APPROVED FOR PUBLIC RELEASE

WHC Information Release Administration Specialist:

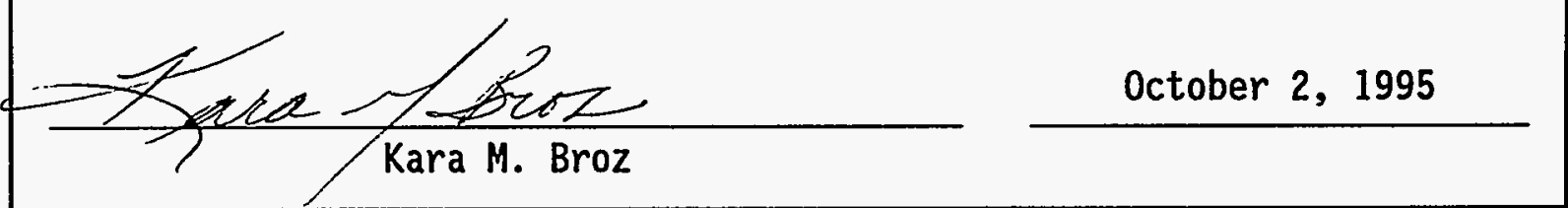




\section{DISCLAIMER}

This report was prepared as an account of work sponsored by an agency of the United States Government. Neither the United States Government nor any agency thereof, nor any of their employees, makes any warranty, express or implied, or assumes any legal liability or responsibility for the accuracy, completeness, or usefulness of any information, apparatus, product, or process disclosed, or represents that its use would not infringe privately owned rights. Reference herein to any specific commercial product, process, or service by trade name, trademark, manufacturer, or otherwise does not necessarily constitute or imply its endorsement, recommendation, or favoring by the United States Government or any agency thereof. The views and opinions of authors expressed herein do not necessarily state or reflect those of the United States Government or any agency thereof. 


\section{DISCLAIMER}

Portions of this document may be illegible in electronic image products. Images are produced from the best available original document. 
PRACTICAL MODELING OF ALUMINUM SPECIES IN HIGH PH WASTE

\author{
D. A. Reynolds
}

\begin{abstract}
One of the main components of the nuclear waste stored at the Hanford Site is aluminum. As efforts are made to dispose of the waste, the need to predict the various phases of the aluminum becomes important for modeling of the disposal processes. Current databases of the aluminum species are not adequate as they stand.
\end{abstract}

This study is not an attempt to present a rigorous discussion of aluminum chemistry, but to approach aluminum solubility as a practical application. The approach considers two different forms of aluminate; $\mathrm{Al}(\mathrm{OH})_{4}^{-}$and $\mathrm{AlO}_{2}^{-}$. By taking both of these forms of aluminate into consideration, a workable system of aluminum chemistry is formed that can be used to model the various waste disposal processes. 
This page intentionally left blank. 


\section{CONTENTS}

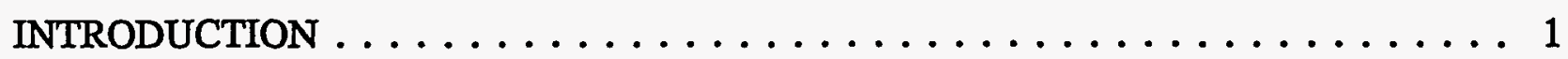
ALUMINUM SPECIES $\ldots \ldots \ldots \ldots \ldots \ldots \ldots \ldots \ldots \ldots \ldots$ EQUILIBRIUM CONSIDERATIONS $\ldots \ldots \ldots \ldots \ldots \ldots \ldots \ldots \ldots$ GIBBSITE SOLUBILITY $\ldots \ldots \ldots \ldots \ldots \ldots \ldots \ldots \ldots \ldots$ SODIUM ALUMINATE SOLUBILITY $\ldots \ldots \ldots \ldots \ldots \ldots \ldots$ TESTING THE SOLUBILITY RELATIONSHIPS . . . . . . . . . . . . . . 13

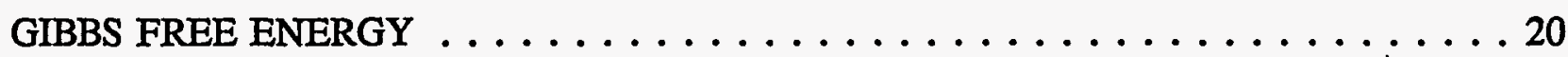

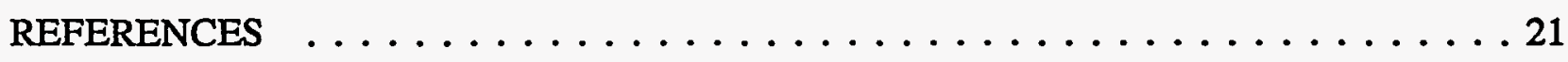


WHC-EP-0872

\section{LIST OF FIGURES}

1 Solubility of Sodium Aluminate in Synthetic Waste Solutions (Saturated with $\mathrm{NaNO}_{3}, \mathrm{NaNO}_{2}, \mathrm{Na}_{2} \mathrm{SO}_{4}$, and $\mathrm{Na}_{2} \mathrm{CO}_{3}$ ) . . . . . . . 4

2 Aluminum Versus Activity of Water $\ldots \ldots \ldots \ldots \ldots \ldots \ldots \ldots \ldots \ldots \ldots$

3 Equilibrium Constant for $\mathrm{Al}(\mathrm{OH})_{4}{ }^{-}=\mathrm{AlO}_{2}{ }^{-}+\mathrm{H}_{2} \mathrm{O} \ldots \ldots \ldots \ldots \ldots$

4 Equilibrium Constant for $\mathrm{Al}(\mathrm{OH})_{3}+\mathrm{OH}^{-}=\mathrm{Al}(\mathrm{OH})_{4}^{-} \ldots \ldots \ldots$

5 Sodium Aluminate Solubility Constant $\ldots \ldots \ldots \ldots \ldots \ldots \ldots$

6 Gibbsite Solubility - Measured vs. Calculated $\ldots \ldots \ldots \ldots \ldots \ldots$

7 Gibbsite Solubility - Ratio $\ldots \ldots \ldots \ldots \ldots \ldots$

8 Aluminate Solubility - Measured vs. Calculated $\ldots \ldots \ldots \ldots \ldots$

9 Aluminate Solubility - Ratio $\ldots \ldots \ldots \ldots \ldots \ldots \ldots$

10 Plant Data Compared to Prediction . . . . . . . . . . . . . . . 19

\section{LIST OF TABLES}

1 Equilibrium Constant $\mathrm{Al}(\mathrm{OH})_{4}^{-}=\mathrm{AlO}_{2}{ }^{-}+\mathrm{H}_{2} \mathrm{O} \ldots \ldots \ldots \ldots \ldots \ldots$

2 Equilibrium Constant $\mathrm{Al}(\mathrm{OH})_{3}+\mathrm{OH}^{-}=\mathrm{Al}(\mathrm{OH})_{4} \ldots \ldots \ldots \ldots$

$3 \mathrm{NaAlO}_{2 \text { (solid) }}=\mathrm{Na}^{+}+\mathrm{AlO}_{2}^{-} \ldots \ldots \ldots \ldots \ldots \ldots \ldots \ldots \ldots \ldots \ldots$ 


\section{INTRODUCTION}

Waste from nuclear reprocessing is being stored in 177 storage tanks at the Hanford Site in Washington State. There are $80,000 \mathrm{~m}^{3}$ (21 million gal) of liquid waste and $153,000 \mathrm{~m}^{3}$ (40 million gal) of solid waste stored in the tanks. The waste is kept caustic to prevent corrosion in the black-iron-lined tanks.

Aluminum is one of the major constituents in the waste. The aluminum entered the waste stream in three ways. First, the uranium fuel used for many years in nuclear reactors was clad with aluminum that was dissolved and discarded before the uranium was dissolved. Second, for corrosion control, aluminum was added to the acid stream after the uranium dissolution to complex with fluoride ion. Finally, aluminum nitrate was added to some chemical processing streams to increase ionic strength and "salt out" certain chemical species.

With increased chemical modeling needs for waste management, a better definition of aluminum chemistry is needed. This study will explore the aluminum chemistry in caustic waste. Aluminum chemistry in acid solutions seems better understood, but caustic solutions are most common in waste management. This study will not try to answer all the questions of aluminum chemistry in caustic solutions but will present a consistent chemical scheme that would be useful in chemical modeling of nuclear waste.

One chemical modeling tool that has been used is the Environmental Simulation Program (ESP) computer program, which has a large database for aqueous chemical species. But the database did not perform well for aluminum chemistry when applied to Hanford Site waste chemistry. It seemed adequate for low concentrations of aluminum; however, the model estimated that essentially all of the aluminum would be in the gibbsite phase at high concentrations of aluminum. Not enough aluminum would remain in solution in the model for the computer program to form a sodium aluminate phase. Yet sodium aluminate is a major aluminum phase in the Hanford Site waste. Clearly, an improved database was needed for aluminum chemistry to be successfully modeled at the Hanford Site.

\section{ALUMINUM SPECIES}

The solid aluminum species that are typically reported from a basic solution fall into two categories. The first category is a sodium salt of an aluminum anion, sodium aluminate, usually shown as $\mathrm{NaAlO}_{2}$ but occasionally as $\mathrm{Na}_{2} \mathrm{O} \cdot \mathrm{Al}_{2} \mathrm{O}_{3}$. The second category is a family of aluminum oxide species with the general form of $\mathrm{Al}_{2} \mathrm{O}_{3} \cdot \mathrm{nH}_{2} \mathrm{O}$. Numerous species are identified in the literature. At the Hanford Site, three forms have been identified. The amorphous aluminum hydroxide and the mineral gibbsite both have the same chemical composition of $\mathrm{Al}(\mathrm{OH})_{3}\left(\mathrm{Al}_{2} \mathrm{O}_{3} \cdot 3 \mathrm{H}_{2} \mathrm{O}\right)$ but differ in that the amorphous aluminum hydroxide does not have a crystal lattice while gibbsite does. Boehmite $\left[\mathrm{AlO}(\mathrm{OH})\right.$ or $\left.\mathrm{Al}_{2} \mathrm{O}_{3} \cdot 1 \mathrm{H}_{2} \mathrm{O}\right]$ has 
also been identified. Sodium aluminate, boehmite, amorphous aluminum hydroxide, and gibbsite have all been identified in Hanford Site waste at one time or another.

The ionic aluminum species present in basic solution has been a matter of speculation for many years (Eremin et al. 1975, Szita and Berecz 1975a and 1975b). While there is some reason to believe that the aluminum species may give polymeric ions with up to 18 aluminum atoms at high aluminum concentration and low hydroxide, for the purpose of modeling, two aluminum species will be sufficient. However, both of these species seem necessary in the models to adequately model the aluminum species.

\section{EQUILIBRIUM CONSIDERATIONS}

Consider the reaction at equilibrium:

$$
M N \rightarrow M+N
$$

A decrease in $\mathrm{N}$ would shift the equilibrium toward the right hand side of the equation. The equilibrium equation for this equation would be:

$$
K_{e q}=\frac{[M] \times[N]}{[M N]}
$$

To keep this equilibrium constant, a decrease in $\mathbf{N}$ would necessitate a decrease in $\mathrm{MN}$.

Two different ionic aluminum species in equilibrium in alkaline solutions are postulated based on the solid phase $\left[\mathrm{Al}(\mathrm{OH})_{3}\right.$ or $\left.\mathrm{NaAlO}_{2}\right]$ controlling their solubilities. The aluminum species are $\mathrm{Al}(\mathrm{OH})_{4}^{-}$and $\mathrm{AlO}_{2}^{-}$.

The $\mathrm{Al}(\mathrm{OH})_{4}{ }_{4}^{-}$species is the form that is in equilibrium with gibbsite $\left[\mathrm{Al}(\mathrm{OH})_{3}\right]$ :

$$
\left.\mathrm{Al}(\mathrm{OH})_{4}^{-}-\mathrm{Al(OH}\right)_{3_{\text {(collco }}}+\mathrm{OH}^{-}
$$


The $\mathrm{AlO}_{2}^{-}$species is the form that is in equilibrium with sodium aluminate:

$$
\mathrm{Na}^{+}+\mathrm{AlO}_{2}^{-} \rightarrow \mathrm{NaAlO}_{2 \text { solid }}
$$

The dissolved aluminum species are also in equilibrium:

$$
\mathrm{Al}(\mathrm{OH})_{4}^{-}-\mathrm{AlO}_{2}^{-}+2 \mathrm{H}_{2} \mathrm{O}
$$

The above equilibrium product in activity terms is defined as:

$$
K_{e q}=\frac{a_{A l O_{2}^{-}} \times a_{\mathrm{H}_{2} \mathrm{O}}^{2}}{a_{\mathrm{Al}(\mathrm{OH})_{4}^{-}}}
$$

By equation 6, decreasing the water activity will decrease the $\mathrm{Al}(\mathrm{OH})_{4}^{-}$and increase $\mathrm{AlO}_{2}$.

The water activity is a function of dissolved salts. The Gibbs-Duhem equation relates the activity of water to activity coefficients of dissolved species. This function shows that the activity of water decreases with added dissolved solids. This is shown by a decreased vapor pressure with dissolved salt. Overall, increased dissolved salts decreases the activity of water. A decrease in the activity of water will shift the aluminum species toward $\mathrm{AlO}_{2}$.

Figure 1 (Barney 1976) is shows solubilities of aluminum species versus sodium hydroxide. The curves with the dotted lines are from literature for the $\mathrm{Na}_{2} \mathrm{O}-\mathrm{Al}_{2} \mathrm{O}_{3}-\mathrm{H}_{2} \mathrm{O}$ system. The curves with the solid lines are from a study that also included sodium nitrate, sodium nitrite, and some minor compounds. The left hand curves show the gibbsite solubility. The area to the left of the curve has solid gibbsite in equilibrium with solution. The curve slopes up, which means that as sodium hydroxide is increased, more aluminum can remain in solution.

The right hand curves show the aluminate solubility curve. Concentrations to the right or above the curve have solid sodium aluminate in equilibrium with aluminum in solution. The space between the two curves represents concentrations that have soluble aluminum with no solid aluminum salt phase.

The curves, as reported by Barney (1976), are shifted toward lower hydroxide concentrations. The major difference between Barney's curves and the literature curves is that Barney had other chemical species besides caustic and aluminum in the solutions. These other chemicals would have increased the ionic strength of the solution, which would have lowered the activity of the water. 
Figure 1. Solubility of Sodium Aluminate in Synthetic Waste Solutions (Saturated with $\mathrm{NaNO}_{3}, \mathrm{NaNO}_{2}, \mathrm{Na}_{2} \mathrm{SO}_{4}$, and $\mathrm{Na}_{2} \mathrm{CO}_{3}$ ).

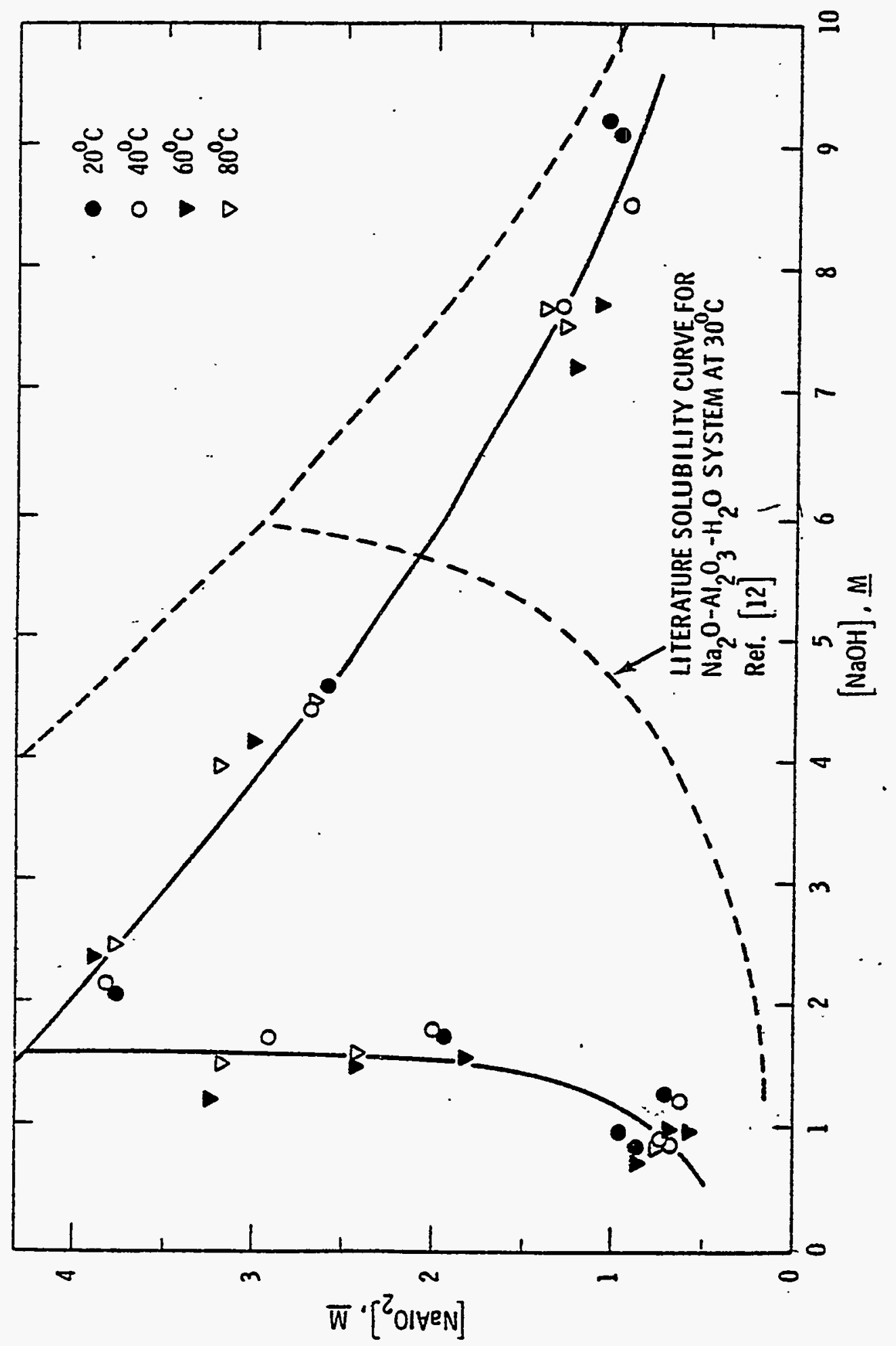


Figure 2 is a plot of aluminum concentration in molality units (moles per $1,000 \mathrm{~g}$ of water) versus the activity of water. For the Barney (1976) data, the activity of water is based on measured vapor pressures. For the other two sets of data, the activity of water was calculated from concentrations and activity coefficients. This plot shows a lot of scatter. While the graph is not intended to show that activity of water is the most important factor in the solubility of aluminum, there does seem to be a relationship between activity of water and the three sets of data. It should be pointed out that Figure 2 is approximately the opposite of Figure 1. In Figure 1, the solution concentration increased from left to right. In Figure 2, the most concentrated solutions are on the left and pure water is on the right. Therefore, the gibbsite region is on the right of Figure 2. The break between gibbsite and sodium aluminate is not as clear in Figure 2. For the Barney (1976) data, the break occurs at approximately 0.4 activity of water, with some scatter around that value. Similarly, the break for the literature data is also at an activity of water of about 0.4. Note that now there is no shift between data from Barney (1976) and literature data. Both breaks occur at approximately the same location on the water activity axis. It should also be noted that sodium hydroxide influences the water activity more than the other species.

Figure 2 shows that the apparent discrepancy between solubilities with or without other salts present can be resolved by plotting against the activity of water. This is strong evidence that the ionic species of aluminum is influenced by the activity of water. The relationship indicated by equations 5 and 6 appears valid.

The value for the equilibrium constant, $\mathrm{K}_{\mathrm{eg}}$, in Equation 6 may be estimated from information given by Raizman et al. (1981). Raizman used some Russian thermodynamic tables not readily available here to estimate the ratio of the activity of the two forms of aluminate ion. The natural $\log$ of the ratio was presented in this article. The aluminate solutions were derived from three different minerals (gibbsite, boehmite, and diaspore) for a range of temperatures. The values for diaspore were not used in this study because the calculated $\mathrm{K}_{\mathrm{eq}}$ values were significantly different from those derived from gibbsite and boehmite.

Figure 3 shows the information presented by Raizman et al. (1981) on the aluminate species derived from two different solid forms. The information was regressed and the regression line is included in this figure.

The regression equation is:

$$
\log K_{e q}=-49.9799+0.112 * T k+\frac{7582}{T k}-8.4 E-05 * T k^{2}
$$

where:

Tk is temperature in Kelvin. The correlation coefficient for this fit is: $R=0.944$. 


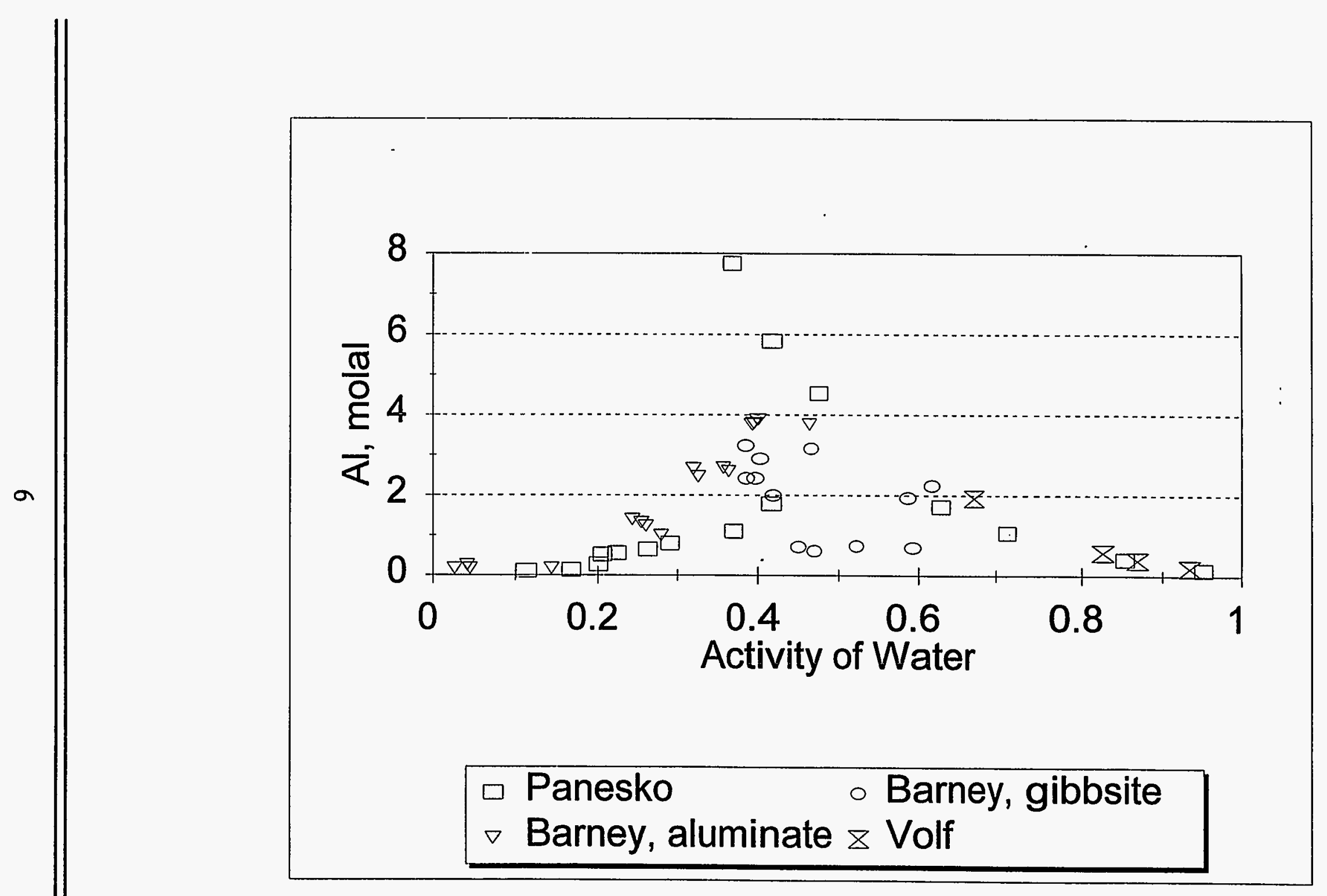


Figure 3. Equilibrium Constant for $\mathrm{Al}(\mathrm{OH})_{4}^{-}=\mathrm{AlO}_{2}^{-}+\mathrm{H}_{2} \mathrm{O}$.

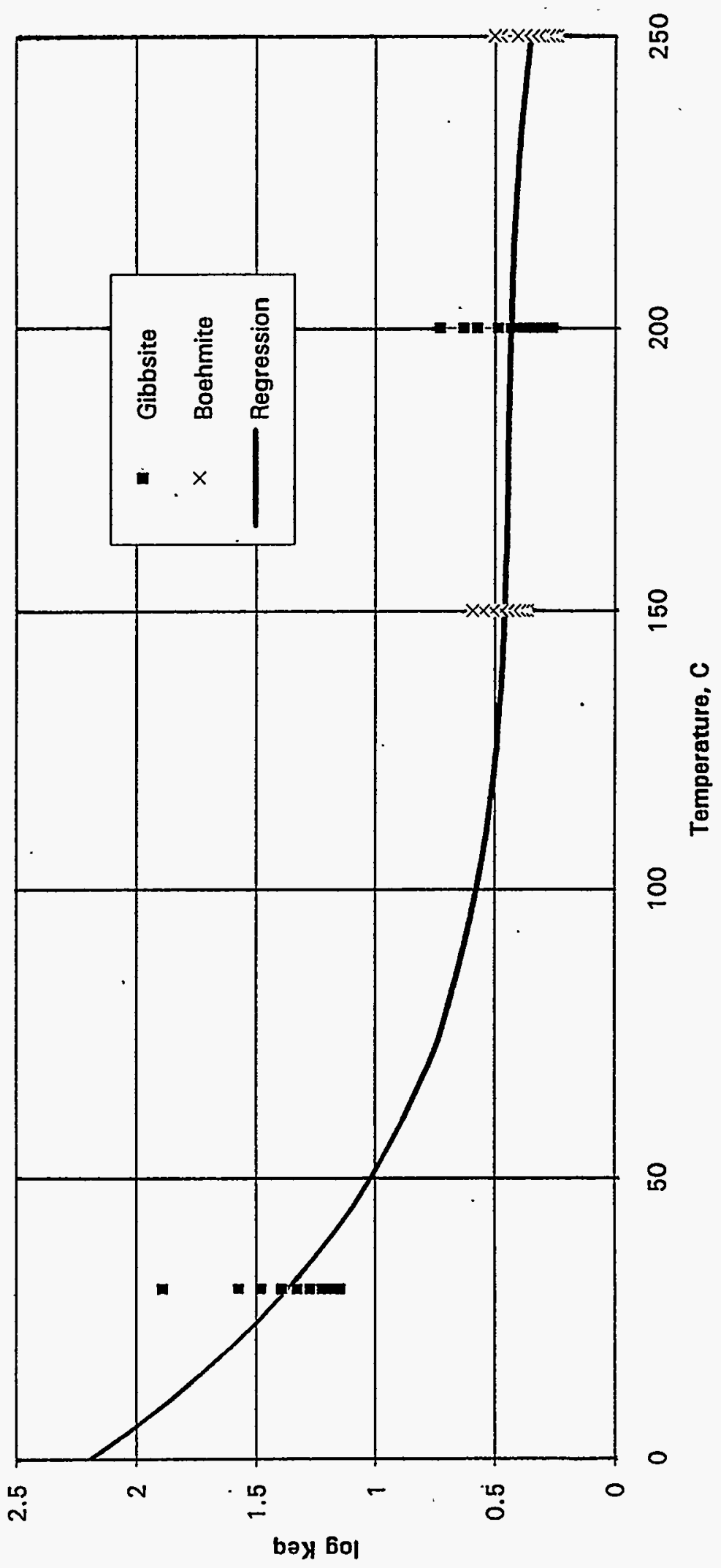


Table 1 shows the values of the equilibrium constant calculated from the regression equation.

Table 1. Equilibrium Constant

$$
\mathrm{Al}(\mathrm{OH})_{4}^{-}=\mathrm{AlO}_{2}^{-}+\mathrm{H}_{2} \mathrm{O} \text {. }
$$

\begin{tabular}{|c|c|c|}
\hline $\mathrm{T},{ }^{\circ} \mathrm{C}$ & $\log _{\mathrm{eq}}$ & $\mathrm{K}_{\text {eq }}$ \\
\hline 0 & 2.19 & 155 \\
\hline 10 & 1.87 & 74.0 \\
\hline 20 & 1.60 & 39.5 \\
\hline 25 & 1.48 & 30.0 \\
\hline 30 & 1.37 & 23.3 \\
\hline 40 & 1.18 & 15.0 \\
\hline 50 & 1.02 & 10.4 \\
\hline 60 & 0.89 & 7.70 \\
\hline 70 & 0.78 & 6.03 \\
\hline 80 & 0.70 & 4.96 \\
\hline 90 & 0.63 & 4.24 \\
\hline 100 & 0.58 & 3.76 \\
\hline 150 & 0.46 & 2.88 \\
\hline 200 & 0.43 & 2.70 \\
\hline 250 & 0.35 & 2.24 \\
\hline
\end{tabular}

The equilibrium favors the formation of $\mathrm{AlO}_{2}^{-}$at all temperatures.

\section{GIBBSITE SOLUBILITY}

Gibbsite solubility has been studied extensively by a large number of investigators. This is not meant to be an exhaustive presentation of all information on gibbsite solubility but rather a practical approach to the solubility. The gibbsite solubility correlation relied on three investigators: the rather recent work by Wesolowski and Palmer (1992); Barney (1976); and Herting and Cleavenger (1985).

Wesolowski and Palmer (1992) found that there was a very good correlation between gibbsite solubility literature and their own work. They used sodium chloride to increase the ionic 
strength, and their ionic strength of solutions extended up to 5 molal. Data were presented for a temperature range from $6.8^{\circ} \mathrm{C}$ to $70^{\circ} \mathrm{C}$. It should be pointed out that the equilibrium constant presented by Wesolowski and Palmer (1992) considered the only ionic aluminum species as $\mathrm{Al}(\mathrm{OH})_{4}^{-}$and cannot be used if $\mathrm{AlO}_{2}^{-}$is considered a species in solution with the equilibrium derived in the preceding section.

Barney (1976) used very concentrated solutions. Typically the solutions were saturated in sodium nitrate, sodium nitrite, sodium carbonate, and sodium sulfate as well as the aluminum species. Ionic strengths extended beyond 20 molal. Temperatures ranged from $20^{\circ} \mathrm{C}$ to $80{ }^{\circ} \mathrm{C}$.

Herting and Cleavenger (1985) did a parametric study of the influence of sodium nitrate, sodium nitrite, and sodium hydroxide on gibbsite solubility. Small amounts of sodium fluoride were present also. The temperature ranged from $40^{\circ} \mathrm{C}$ to $80^{\circ} \mathrm{C}$. Equation 8 shows the gibbsite solubility:

$$
A l(O H)_{3}(\text { solid })+\mathrm{OH}^{-}=A l(O H)_{4}^{-} .
$$

Certain data from each of these data sets were selected. The entire data set was not used to allow for some points that could be used as checks on the validity of the equilibrium correlation. The ESP't computer code was used to calculate the equilibrium constant for the solubility equation. A model was made with the appropriate chemical species. No solids were allowed in the model so that all chemical species were in the solution phase. The $\mathrm{Al}(\mathrm{OH})_{4}{ }^{-} / \mathrm{AlO}_{2}^{-}$equilibrium from Table 2 was used. The input to the model was the experimental data from the various investigators. Each investigator presented the amount of aluminum in solution at equilibrium. The computer model then calculated the equilibrium product based on the amount of aluminum, activity coefficients of all ions, temperature, and activity of water.

Figure 4 shows the resulting equilibrium constants along with the regression line for the data. The points from Bamey (1976) seem slightly low but overall the three data sets correspond well.

The equation for the regression is:

$$
\log K_{e q}(\text { gibbsite })=-365.8+\frac{36458.6}{T k}+1.173 * T k .-.00123 * T k^{2}
$$

The correlation coefficient for this fit is: $R=0.958$. 


\section{WHC-EP-0872}

Figure 4. Equilibrium Constant for $\mathrm{Al}(\mathrm{OH})_{3}+\mathrm{OH}^{-}=\mathrm{Al}(\mathrm{OH})_{4}^{-}$.

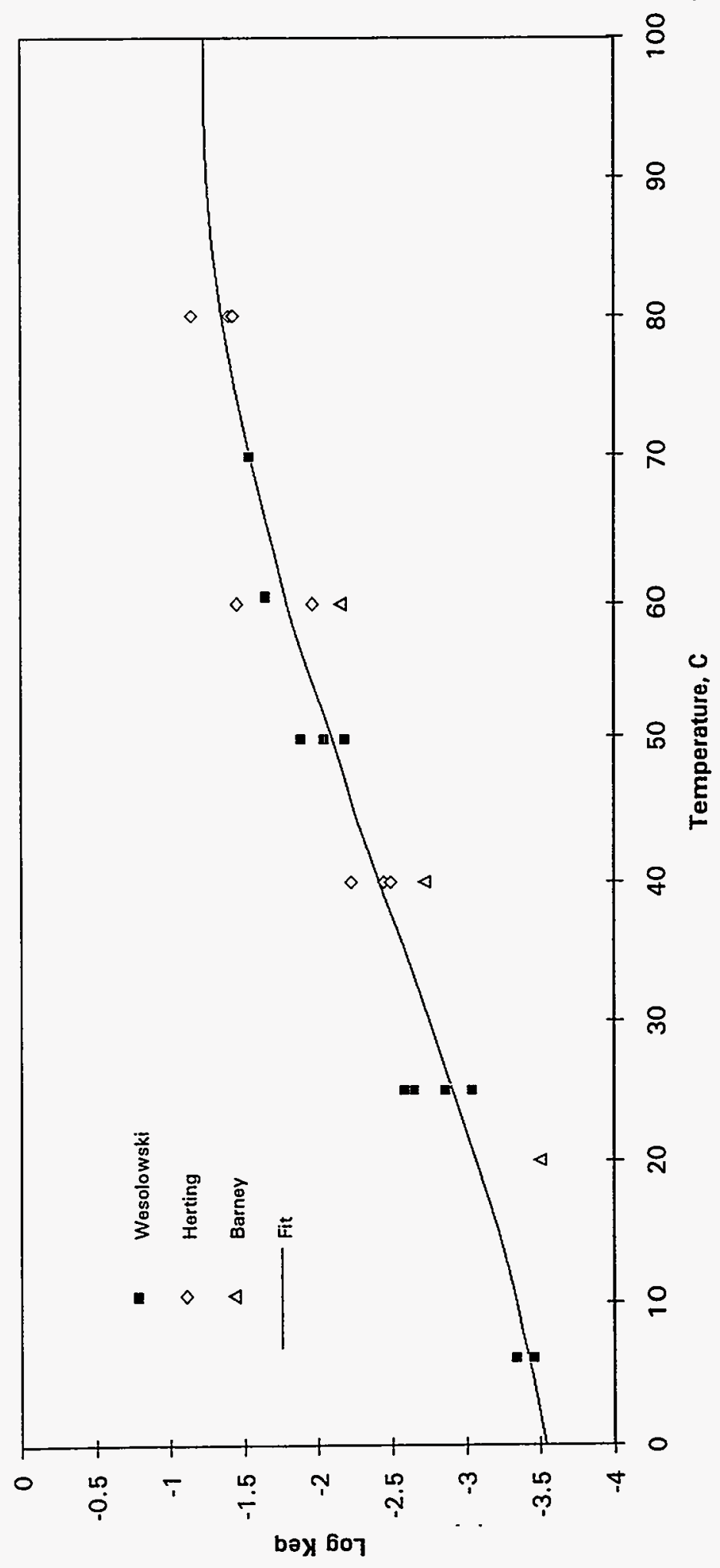


A table of values is given in Table 2.

Table 2. Equilibrium Constant

$\mathrm{Al}(\mathrm{OH})_{3}+\mathrm{OH}^{-}=\mathrm{Al}(\mathrm{OH})_{4}$.

\begin{tabular}{|c|c|c|}
\hline $\mathrm{T},{ }^{\circ} \mathrm{C}$ & Log Keq & Keq \\
\hline 0 & -3.54 & 0.0003 \\
\hline 10 & -3.34 & 0.0005 \\
\hline 20 & -3.07 & 0.0009 \\
\hline 25 & -2.91 & 0.0012 \\
\hline 30 & -2.75 & 0.0018 \\
\hline 40 & -2.41 & 0.0039 \\
\hline 50 & -2.09 & 0.0082 \\
\hline 60 & -1.79 & 0.0163 \\
\hline 70 & -1.54 & 0.0289 \\
\hline 80 & -1.35 & 0.0442 \\
\hline 90 & -1.25 & 0.0564 \\
\hline 100 & -1.24 & 0.0580 \\
\hline
\end{tabular}

\section{SODIUM ALUMINATE SOLUBILITY}

Far fewer studies have been done on sodium aluminate solubility than on gibbsite solubility. A comprehensive sodium aluminate solubility study was not attempted here. Studies by Reynolds and Herting (1984) and Barney (1976) were used heavily. In addition, Panasko and Yashunin (1964) and Volf and Kuznetsov (1955) were used.

The equilibrium constant for the sodium aluminate dissolution was estimated using Reynolds and Herting (1984) and Barney (1976) data. The ESP ${ }^{\mathrm{TM}}$ computer code was used again in a similar manner as for the gibbsite solubility. Both studies were needed to provide a wide temperature range. Figure 5 shows the points used and the resulting regression. A straight line regression was used for this case, which seemed to be adequate to represent the points.

The regression equation is:

$$
\log \mathrm{K}_{\mathrm{eq}} \text { (sodium aluminate) }=0.7429+0.002148 * \mathrm{Tk} .
$$

The correlation coefficient for this fit is: $R=0.488$. 


\section{WHC-EP-0872}

Figure 5. Sodium Aluminate Solubility Constant.

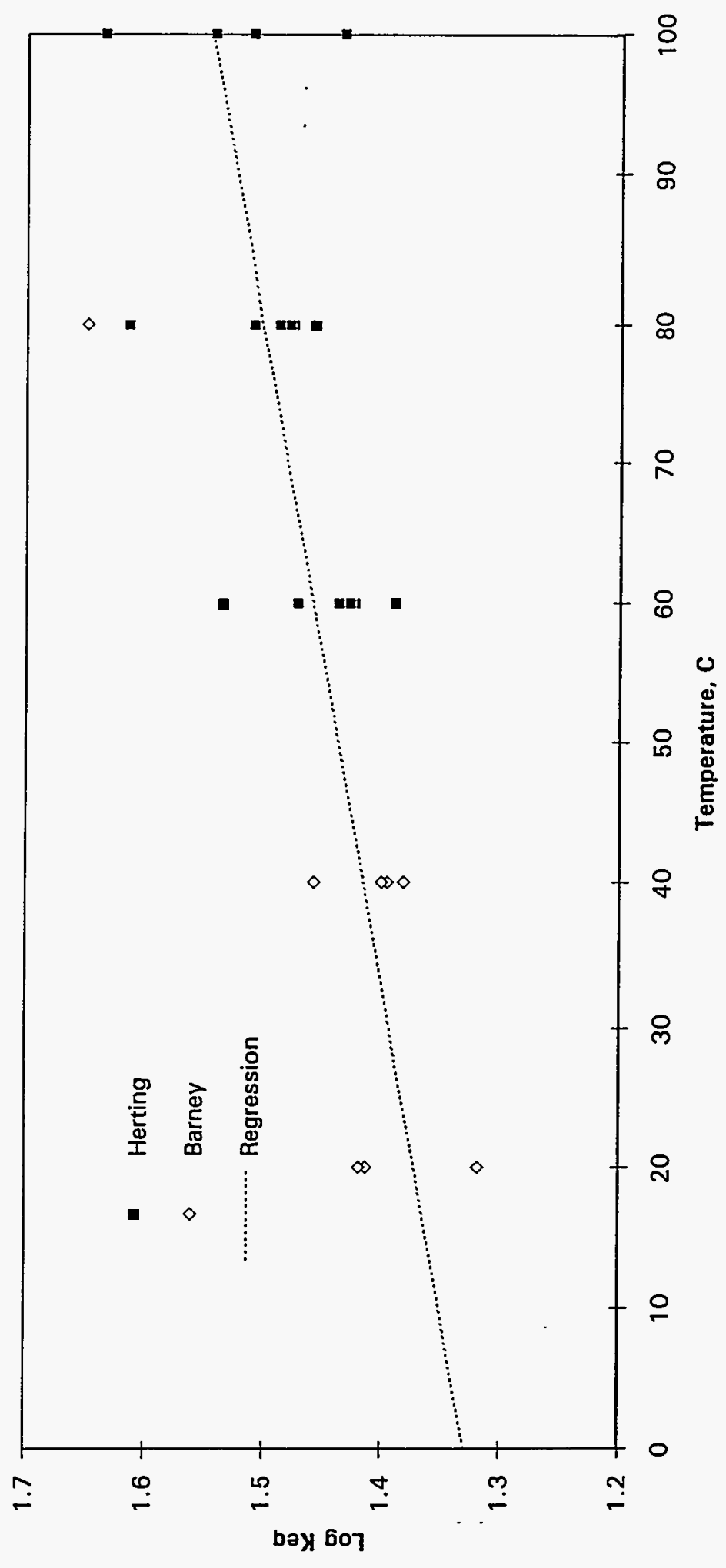


Table 3 shows the values calculated by that equation.

Table 3. $\mathrm{NaAlO}_{2 \text { (solid) }}=\mathrm{Na}^{+}+\mathrm{AlO}_{2}^{-}$.

\begin{tabular}{|c|c|c|}
\hline $\mathrm{T},{ }^{\circ} \mathrm{C}$ & $\log \mathrm{K}_{\text {eq }}$ & $\mathrm{K}_{\text {eq }}$ \\
\hline 0 & 1.33 & 21.4 \\
\hline 10 & 1.35 & 22.4 \\
\hline 20 & 1.37 & 23.6 \\
\hline 25 & 1.38 & 24.2 \\
\hline 30 & 1.39 & 24.8 \\
\hline 40 & 1.42 & 26.0 \\
\hline 50 & 1.44 & 27.4 \\
\hline 60 & 1.46 & 28.7 \\
\hline 70 & 1.48 & 30.2 \\
\hline 80 & 1.50 & 31.7 \\
\hline 90 & 1.52 & 33.3 \\
\hline 100 & 1.54 & 35.0 \\
\hline
\end{tabular}

\section{TESTING THE SOLUBILITY RELATIONSHIPS}

The validity of the solubility relationships was tested by comparing predicted and measured values. Two types of data were used. The first type of data is a subset taken from the technical literature used to produce the prediction equations. This subset was not used in deriving the regressions, to prevent showing that the regression gives the same numbers that the regression was based on. The other type of data was actual tank samples.

The ESP ${ }^{\mathrm{TM}}$ computer program was used with a new database that includes the aluminum equilibrium discussed above. The data was input to the program, which estimated the solubilities of various species. 


\section{WHC-EP-0872}

Figure 6. Gibbsite Solubility - Measured vs. Calculated.

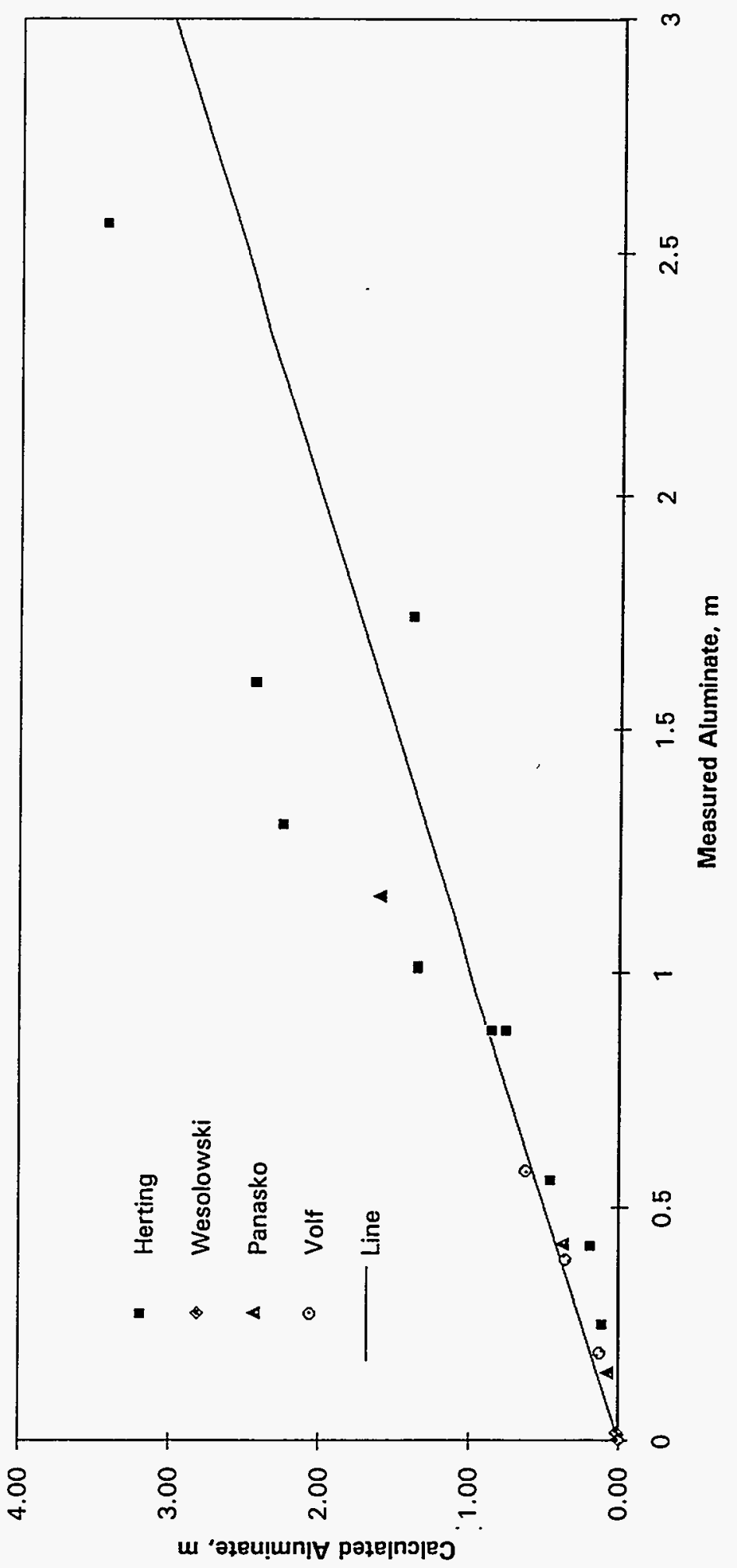




\section{Gibbsite Tests}

Figure 6 shows the calculated aluminum in solution versus measured aluminum in solution when solid gibbsite is present. Note that Panasko and Yashunin (1964) and Volf and Kuznetsov (1955) are literature values that were not used in the derivation of the gibbsite equilibrium constants. The line represents a correlation where the calculated would match the measured. While the points tend to lie along the line, there is a range.

Figure 7 shows another way that this information can be displayed. The line represents a perfect correlation: the calculated matches the measured. The ratio tends to increase with increasing aluminum in solution. The bulk of the points indicate that the calculated values are within $\pm 40 \%$ of the measured values.

Looking back to Figure 4, the range of $\log \mathrm{K}_{\mathrm{eq}}$ at any temperature shows a range. A $40 \%$ range in the value of $\mathrm{K}_{\mathrm{eq}}$ is displayed. Therefore, the information given in Figures 6 and 7 shows ranges within the uncertainty of the data.

\section{Aluminate Tests}

Tests were made on the sodium aluminate side. Figure 8 shows the calculated aluminum in solution versus the measured aluminum in solution when sodium aluminate is present. The lines represents a perfect correlation: the calculated matches the measured. A scatter about that line is shown.

Figure 9 shows the test cases in the ratio form. Once again, the line represents a perfect correlation: the calculated matches the measured. Most of the test cases fall within the $\pm 40 \%$ range.

\section{Process Tests}

The real tests compare the predictions with the actual process streams. For these tests, a random sample of laboratory analyses of the product stream from the waste concentrator was used. A number of these stream analyses were used as input to the predictions. Most of the predictions indicated no aluminate was formed. This was an improvement over previous predictions that indicated that gibbsite formed frequently. There were five cases where the predictions indicated that aluminum salts precipitated. Figure 10 shows these points plotted against the Barney (1976) curve. (Four cases can be seen as "diamonds." The point at approximately $4.5 \mathrm{M} \mathrm{OH}$ is a double point where the lab results plot on top of the $\mathrm{Al}(\mathrm{OH})_{3}$ point.) The process samples are plotted along with the prediction. Four of the predicted aluminum salts lie near the Barney (1976) curve for the solubility of sodium aluminate. In three of these cases the laboratory information places the solutions in the region where sodium aluminate would be present in the solid phase. The fourth test is very close to the boundary line. It should be pointed out that sodium aluminate precipitates out very slowly. 
Figure 7. Gibbsite Solubility - Ratio.
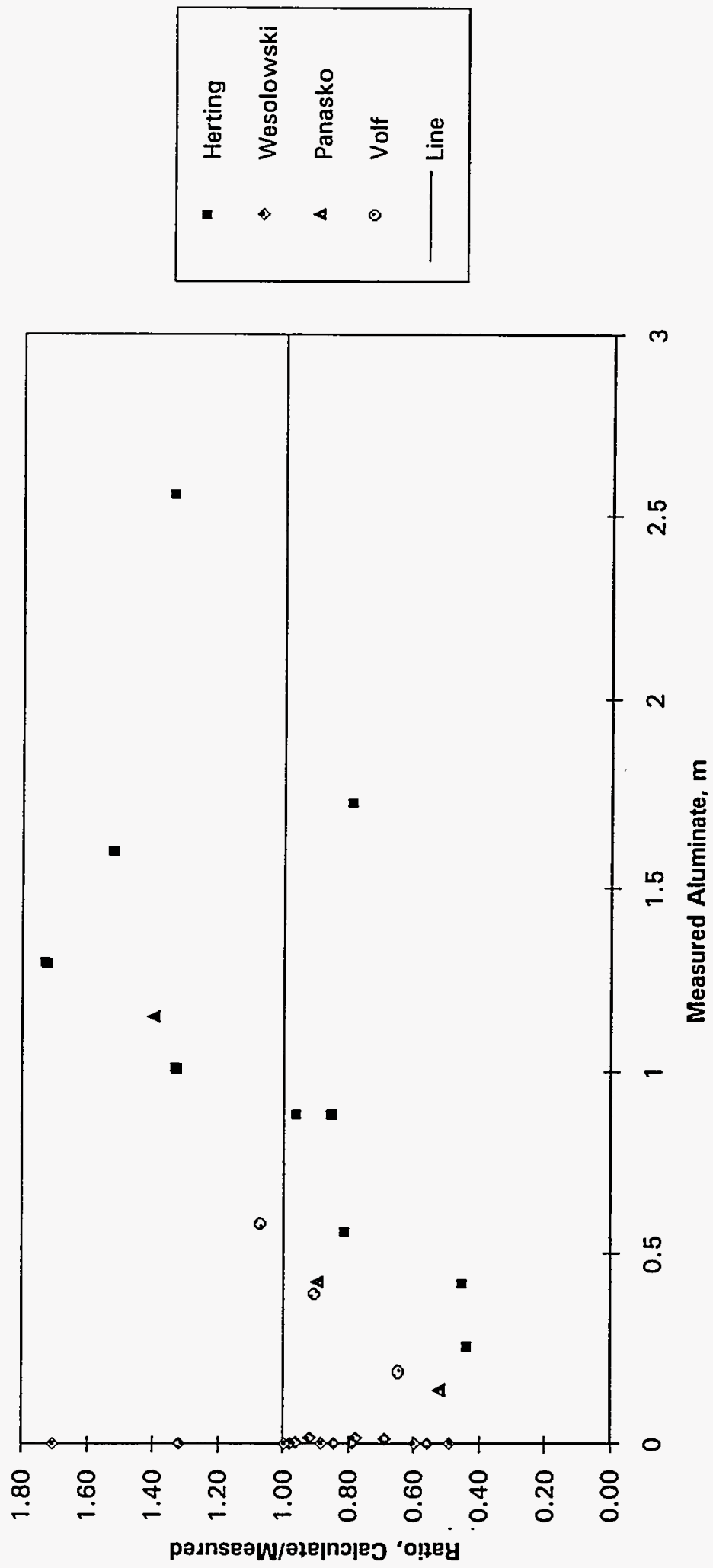
Figure 8. Aluminate Solubility - Measured vs. Calculated.

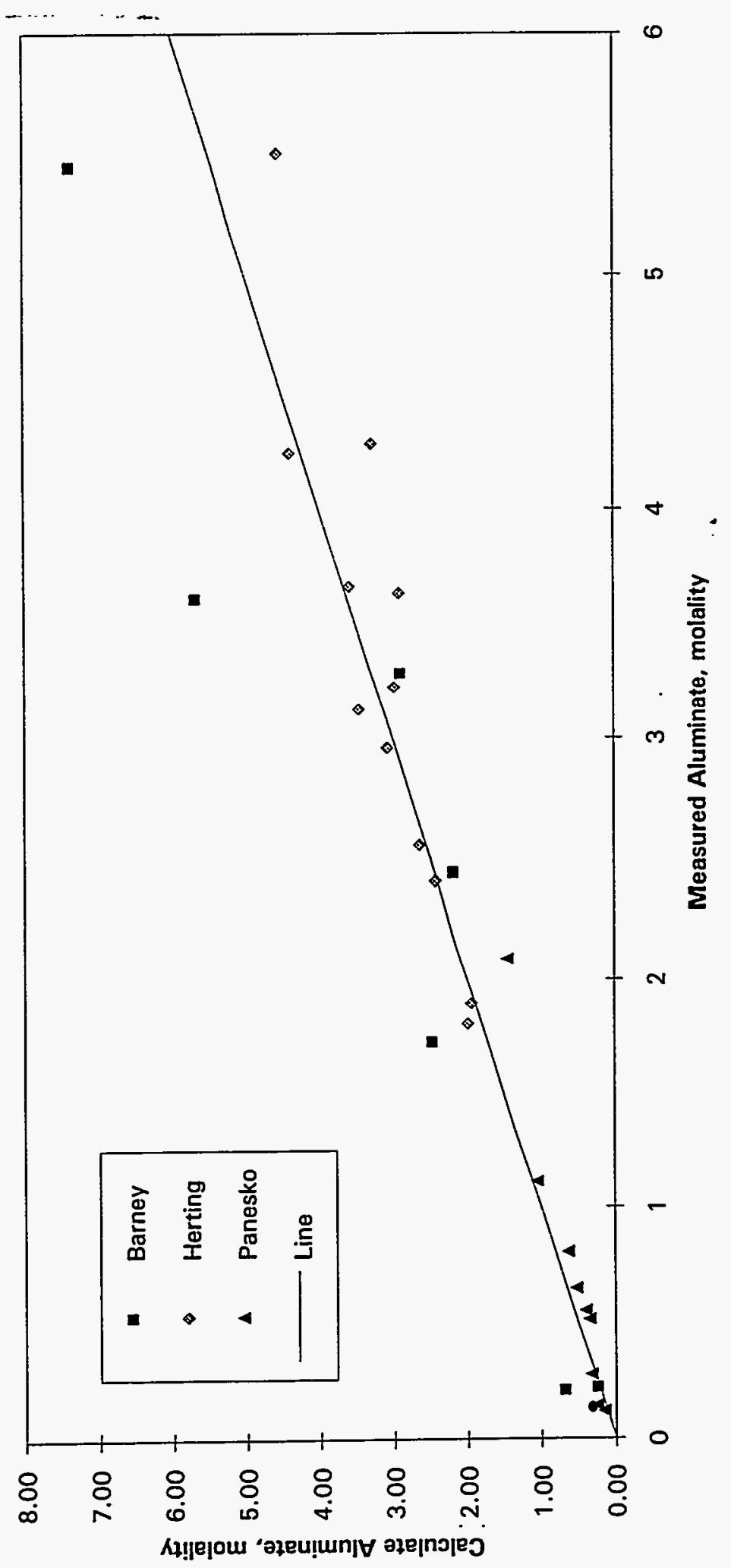




\section{WHC-EP-0872}

Figure 9. Aluminate Solubility - Ratio.

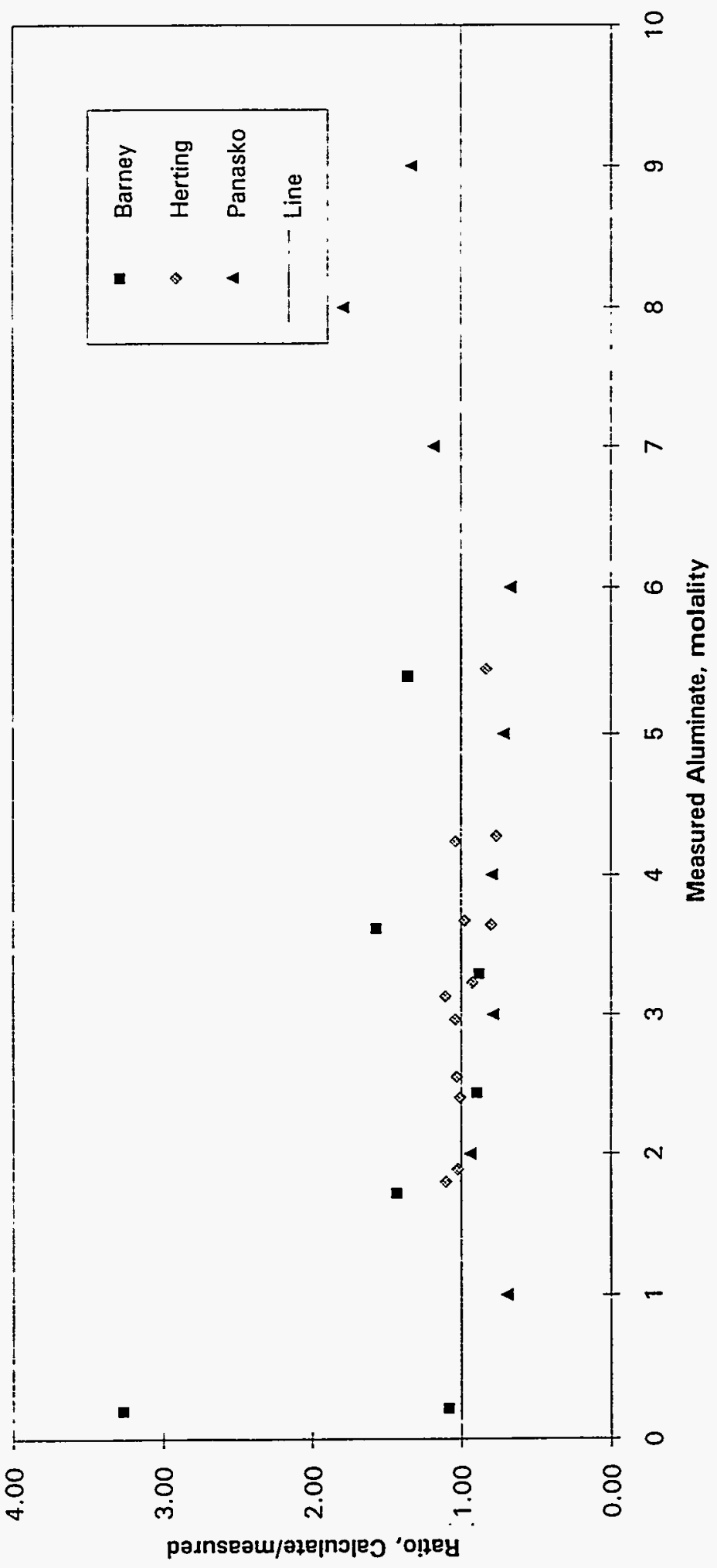


Figure 10. Plant Data Compared to Prediction.

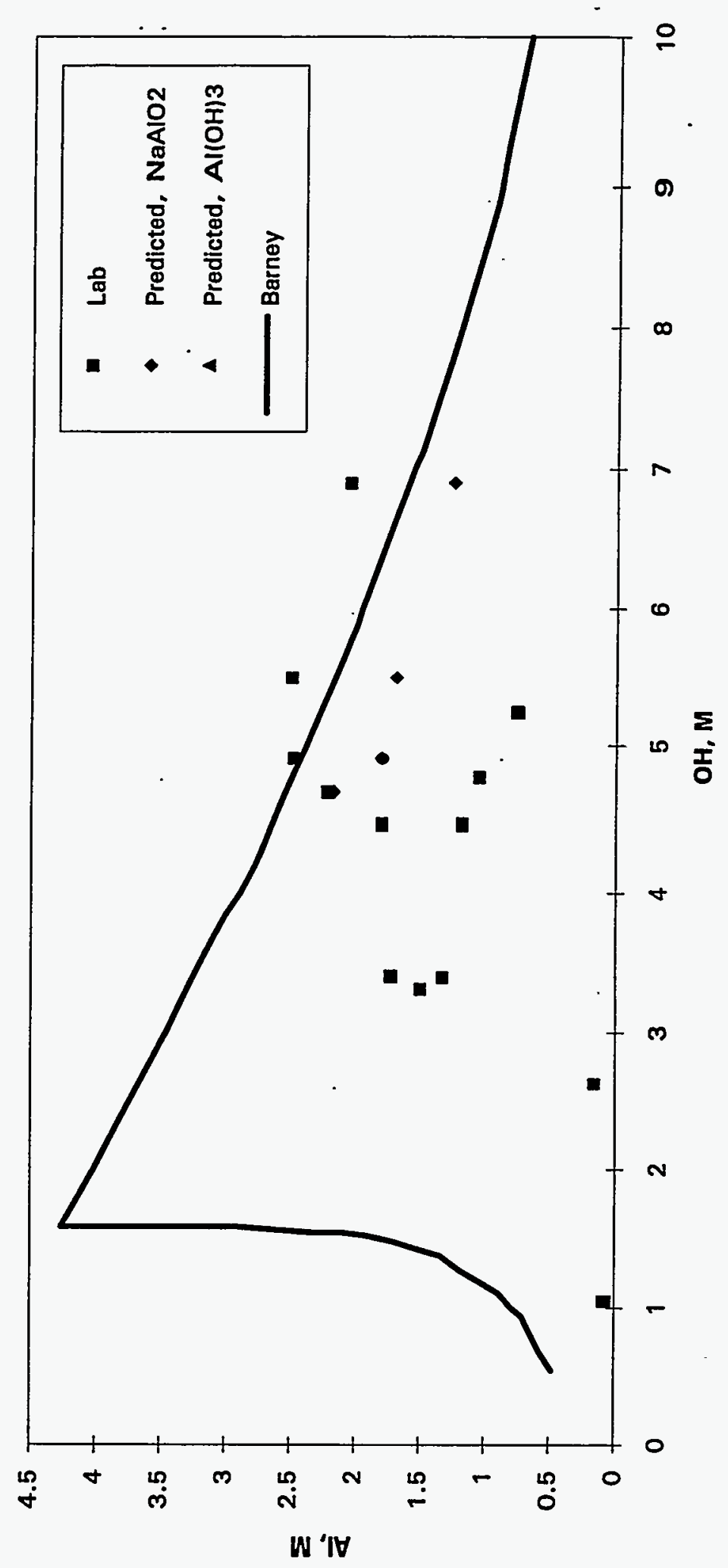


Laboratory analysis may represent a solution supersaturated in sodium aluminate. In any case, the prediction shows sodium aluminate precipitating at approximately the same place as the line representing the sodium aluminate boundary. It should be noted that the sodium aluminate was never predicted to precipitate out on the previous database. The fifth case shows a dilute stream. The prediction indicates that gibbsite precipitated; the laboratory sample does not. However, this region of the solubility curve is considered soft by process engineers, and caution has always been used in this region.

Overall, the new database performed well. It predicted aluminum solids when expected and no solids when unexpected.

It should be noted that at the peaks of the solubility curves as shown in Figure 10, the predictions do not work well. This is not a practical problem, as most waste at the Hanford Site is not in that region.

\section{GIBBS FREE ENERGY}

Now that the equilibrium constants have been found for the various steps going from gibbsite to sodium aluminate, the Gibbs free energy for the various species can be found. The method used was to start with a literature value for gibbsite and proceed from there. The following equation relates the Gibbs free energy and the equilibrium constant:

$$
\ln (K e q)=\frac{-\Delta G^{\circ}}{R \times T}
$$

In this equation, $R$ is the gas constant, $T$ is temperature, and $\Delta G$ is the difference between the sum of the Gibbs free energy of the products and the reactants.

Table 4 shows the results of this study. Also included are some additional literature values. The major difference is between values for gibbsite $\left(\mathrm{Al}(\mathrm{OH})_{3}\right)$ from Wagman et al. (1982) and Hemmingway et al. (1978) The value from Hemmingway and Robie (1977) was used as the starting point for this study.

Table 4. Gibbs Free Energy kJ/mole.

\begin{tabular}{|c|c|c|c|l|}
\hline $\mathrm{Al}(\mathrm{OH})_{3}$ & $\mathrm{Al}(\mathrm{OH})_{4}^{-}$ & $\mathrm{AlO}_{2}^{-}$ & $\mathrm{NaAlO}_{2}$ & \multicolumn{1}{|c|}{ Reference } \\
\hline & -1295.54 & -829.72 & -1083.75 & This study \\
\hline-2310.21 & -1305.3 & -830.9 & -1071.32 & Wagman et al. 1982 \\
\hline & -1305.6 & & & Wesolowski and Palmer 1992 \\
\hline-1154.9 & & & & Hemmingway et al. 1978 \\
\hline-1150.68 & -1304.9 & -830.57 & & $\begin{array}{l}\text { Apps et al. 1989 } \\
\text { Apps and Neil 1990 }\end{array}$ \\
\hline
\end{tabular}




\section{REFERENCES}

Apps, J. A., and J. M. Neil, 1990, "Solubilities of Aluminum Hydroxides and Oxyhydroxides in Alkaline Solutions," ACS Symposium Series 416, Chemical Modeling of Aqueous Systems II, Chapter 32.

Apps, J. A., J. M. Neil, and C. H. Jun, 1989, Thermochemical Properties of Gibbsite, Bayerite, Boehmite, Diaspore, and the Aluminate Ion Between 0 and $350^{\circ} \mathrm{C}$, NUREG/CR-5271.

Barney, G. S., 1976, Vapor-Liquid-Solid Phase Equilibria of Radioactive Sodium Salt Wastes at Hanford, ARH-ST-133, Atlantic Richfield Hanford Company, Richland, Washington.

Eremin, N. I., Yu. A. Volokhov, and V. E. Mironov, 1975, "Structure and Behavior of Aluminate Ions in Solution," Russian Chem. Rev., 43, p. 92.

Hemmingway, B. S., and R. A. Robie, 1977, "Enthalpies of Formation of Low Albite ( $\left.\mathrm{NaAlSi}_{3} \mathrm{O}_{8}\right)$, Gibbsite $\left(\mathrm{Al}(\mathrm{OH})_{3}\right)$, and $\mathrm{NaAlO}_{2}$; Revised Values for $\Delta \mathrm{H}$ and $\Delta \mathrm{G}$ of Some Aluminosilicate Minerals," J. Res. USGS 5, pp. 413-429.

Hemmingway, B. S., R. A. Robie, and J. A. Kittrick, 1978, "Revised Values for the Gibbs Free Energy of Formation of $\left[\mathrm{Al}(\mathrm{OH})_{4}{ }_{4}^{-}\right]$, Disaspore, Boehmite and Bayerite at $298.15 \mathrm{~K}$ and $12 \mathrm{Bar}$, the Thermodynamics of Kaolinite to $800 \mathrm{~K}$ and $1 \mathrm{Bar}$, and the Heats of Solution of Several Gibbsite Samples," Geochim. Cosmochim. Acta 42, pp. 1533-1543

Herting, D. L., and R. M. Cleavenger, 1985, Gibbsite Solubility, (internal letter 65453-85-098 to D. A. Reynolds, May 16), Rockwell Hanford Operations, Richland, Washington.

Panasko, G. A., and P. V. Yashunin, 1964, "Calculations for the $\mathrm{Na}_{2} \mathrm{O}-\mathrm{Al}_{2} \mathrm{O}_{3}-\mathrm{H}_{2} \mathrm{O}$ System," J. App. Chem. USSR, ㄱ, p. 298.

Raizman, V. L., L. V. Puchkov, I. Z. Pevzner, and M. M. Neusikhin, 1981, "Thermodynamic Estimation of the Constitution of Singly Charged Aluminum-bearing Ions in Aluminate Solutions in the Aluminum Hydroxide -- Sodium Hydroxide -Water System," Zhur. Obshchei Khim, 51, 5, pp. 972-976.

Reynolds, D. A., and D. L. Herting, 1984, Solubilities of Sodium Nitrate, Sodium Nitrite, and Sodium Aluminate in Simulated Nuclear Waste, RHO-RE-ST-14P, Rockwell Hanford Operations, Richland, Washington. 
Szita L., and E. Berecz, 1975a, "The Structure of Sodium Aluminate Liquors I.," Magy. Kem. Polyoirat, 1, p. 383.

Szita L., and E. Berecz, 1975b, "The Structure of Sodium Aluminate Liquors II.," Magy. Kem. Polyoirat, $\underline{81}$, p. 386.

Volf, F. F., and S. I. Kuznetsov, 1955, "Polytherms in the $\mathrm{Al}_{2} \mathrm{O}_{3}-\mathrm{Na}_{2} \mathrm{O}-\mathrm{H}_{2} \mathrm{O}$ System," Zh. Prikl. Khim., Vol. 28: p. 597.

Wagman, D. D., W. H. Evans, V. B. Parker, R. H. Schumm, I. Halow, S. M. Bailey, K. L. Churney, and R. L. Nuttall, 1982, "The NBS Tables of Chemical Thermodynamic Properties: Selected Values for Inorganic and $\mathrm{C}_{1}$ and $\mathrm{C}_{2}$ Organic Substances in SI Units," J. Phy. and Chem. Reference Data, Vol. 11, Supplement No. 2, p. 2-127.

Wesolowski, D. J., and D. A. Palmer, 1992, "Experimental Studies of Aluminum Solubility and Speciation in Brines," CONF-920761-4, Geochimica et Cosmochimica Acta, vol. 56, pp. 1065-1091. 


\section{DISTRIBUTION}

Number of Copies

OFFSITE

1

Los Alamos National Laboratory

Mail Stop C346

Los Alamos, NM 87545

S. F. Agnew

1

Westinghouse Savannah River

Mail Stop 676T

P. O. Box 616

Aiken, SC 29808

Dan McCabe

Number of Copies

ONSITE

2

U.S. Department of Energy -

Richland Operations Office

D. H. Alexander

S7-51

G. W. Rosenwald

S7-54

3

Pacific Northwest Laboratory

A. R. Felmy

K6-82

W. G. Richmond

P2-35

L. J. Silva

K2-47

20

Westinghouse Hanford Company

H. Babad

S7-30

G. S. Barney

T5-12

K. D. Boomer

H5-49 


\section{DISTRIBUTION (continued)}

Number of Copies

ONSITE

Westinghouse Hanford Company (continued)

T. D. Cooper

C. H. Delegard

D. L. Herting

N. W. Kirch

B. J. Knutson

G. T. MacLean

D. A. Reynolds (5)

OSTI

Central Files (2)

TFIC

DOE Public Reading Room

Hanford Technical Library
T5-12

T6-09

T6-09

R2-11

L0-14

H5-49

R2-11

A3-36

A3-88

R1-20

$\mathrm{H} 2-53$

P8-55 